\title{
KÉMIAI NOBEL-DÍJ, 2020 \\ NOBEL PRIZE IN CHEMISTRY, 2020
}

\author{
Varga Máté \\ PhD, habil. egyetemi docens, Eötvös Loránd Tudományegyetem Genetikai Tanszék Biológiai Intézet, Budapest \\ mvarga@ttk.elte.hu
}

\begin{abstract}
ÖSSZEFOGLALÁS
A 2020-as kémiai Nobel-díj nyertesei, Emmanuelle Charpentier és Jennifer Doudna a baktériumok fágellenes védekezésében kulcsfontosságú CRISPR-rendszer működésének mechanizmusát tárták fel. Munkájuk nemcsak fontos állomása volt annak a folyamatnak, amely a bakteriális genomban levő furcsa, palindrom ismétlődések felismerésétől a prokarióták kvázi-immunrendszerének leírásáig vezetett, de egyben kiindulópontja azoknak a forradalmi genomszerkesztési eljárásoknak, amelyek alaposan felforgatták a biotechnológia és a génterápiás eljárások világát is.
\end{abstract}

\section{ABSTRACT}

The 2020 Nobel Prize in Chemistry was awarded to Emmanuelle Charpentier and Jennifer Doudna for their pioneering work uncovering the molecular mechanism of the bacterial anti-phage CRISPR system. This work was an important milestone in discovering the role of (once obscure) palindromic repeats of the bacterial genome in prokaryotic immunity. And it also inspired the development of novel genome editing tools that revolutionized biotechnology and inspired novel gene therapies.

Kulcsszavak: CRISPR/Cas9, genomszerkesztés, tudománytörténet

Keywords: CRISPR/Cas9, genome editing, history of science

A Svéd Királyi Tudományos Akadémia döntése szerint a 2020-as kémiai Nobel-díjat Emmanuel Charpentier és Jennifer Doudna kapta „egy genomszerkesztési eljárás kifejlesztéséért". Az utóbbi években már többször is a díj esélyeseként emlegetett páros alig több mint kilenc évvel ezelőtt, az Amerikai Mikrobiológiai Társasaság Puerto Rico-i konferenciáján találkozott először, ahol a közös érdeklődés hozta össze őket: mindketten egy sokak számára akkor még obskurus, de potenciálisan nagyon érdekes rendszert tanulmányoztak, amely egyes feltételezések szerint a baktériumsejtek egyfajta immunrendszereként müködhet, megvédve őket saját vírusaik, a bakteriofágok támadásától. 


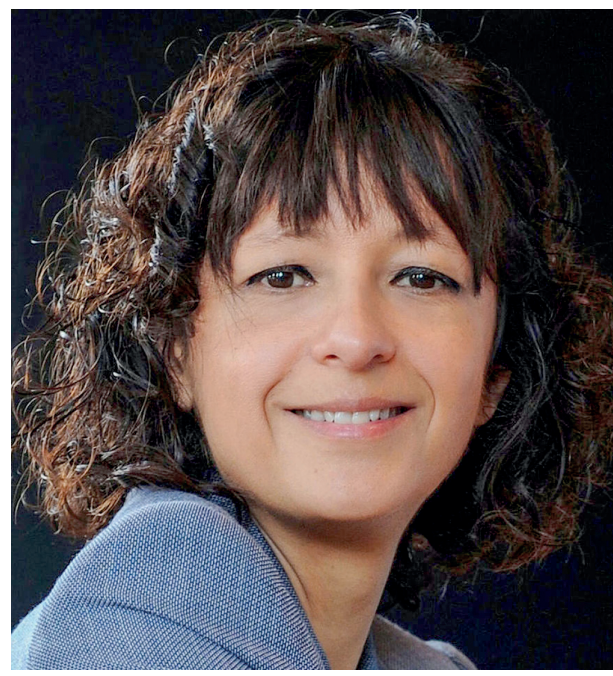

Emmanuelle Charpentier

(Bianca Fioretti, Hallbauer \& Fioretti, CC BY-SA 4.0 via Wikimedia Commons)

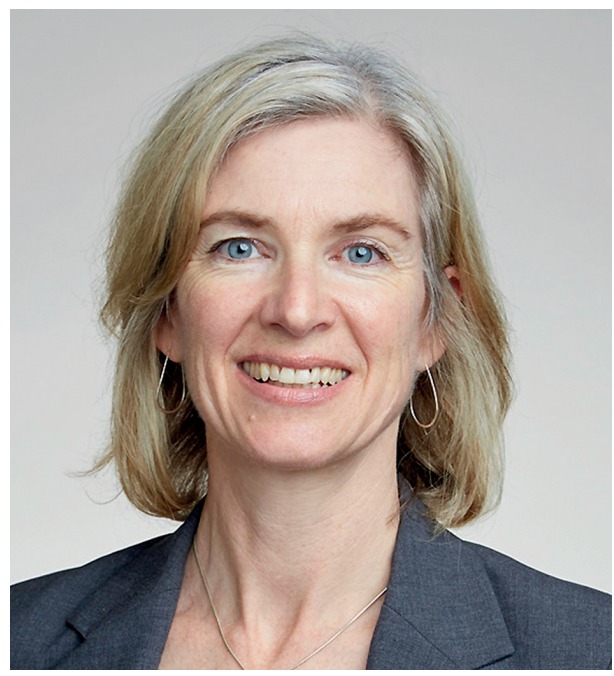

Jennifer Doudna

(The Royal Society, CC BY-SA 3.0, via Wikimedia Commons)

Az elöször csak furcsa, klaszterbe rendezett genomi ismétlődések alapján 1987ben felfedezett CRISPR-rendszer (Clustered Regularly Interspersed Palindromic Repeats) valódi funkciójának megsejtéséhez közel két évtizedre volt szükség, majd a Danisco cég kutatói igazolták, hogy ezeknek valamiképp tényleg a fágok elleni védekezésben lehet szerepük. Charpentier és Doudna csoportjai annak az ekkor még igen kicsi kutatói közösségnek voltak tagjai, amelynek célja a rendszer pontos müködésének feltárása volt, ezért könnyen megtalálták a közös témát és hangot. A San Juan-i kávézóban kezdődött együttmüködés mindössze egy év alatt igazi forradalmi áttörést hozott, és 2012-ben megjelent cikkükben a kutatók részletesen leírták, miképp müködik a rendszer, ami „molekuláris ollóként” képes a DNS hasítására. Mivel alig néhány hónap alatt világossá vált, hogy ez a rendszer nemcsak bakteriális sejtekben, de gyakorlatilag minden élölényben működőképes, a felfedezés méltán hozott világhírt a két kutató számára. Azóta szinte nincs is olyan hét, hogy ne halljunk egy szenzációs felfedezésről, ami valahogy ebből a munkából eredeztethető: ritka és kevésbé ritka emberi betegségek gyógyítása, haszonnövények és tenyészállatok új jellegeinek kialakítása, betegségeket hordozó rovarok elleni védekezés és kihalt fajok „,eltámasztása” - a színes lista mutatja, hogy hányfajta kérdés megválaszolása felé nyitotta tágra a kapukat Doudna és Charpentier felfedezése. Persze, ahogy azt a 2018-as év, Csiankuj He (He Jiankui) nevéhez kapcsolható negatív szenzációja, a génszerkesztett ikerlányok születése is világossá tette, nincs az a tudományos eredmény, ami rossz kezekben kárt ne tudna okozni. 
Talán túlzás nélkül lehet azt mondani, hogy a Charpentier-Doudna páros nevével fémjelzett felfedezés évek múlva hasonló jelentőségünek tünik majd, mint két generációval ezelőtt James Watson és Francis Crick kettős hélixe. De ugyanúgy, ahogy Crick és Watson sem légüres térben dolgozott, hanem Linus Pauling, Erwin Chargaff és föként Rosalind Franklin, Maurice Wilkins és Raymond Gosling eredményei alapján érhette el az áttörést, ugyanúgy Charpentier és Doudna felfedezését és megérdemelt Nobel-díját számos más kutató munkája tette lehetövé, akiknek a nevét szintén nem szabad elfelednünk, ha a CRISPR jelentőségéröl esik szó. A furcsa CRISPR-szekvenciákat felfedező Ishino Josijumi (Yoshiyumi Ishino), azoknak a bakteriális immunitásban betöltött szerepét megsejtő Francisco Mojica és Eugene Koonin, a szerepet bizonyító Rodolphe Barrangou, valamint Doudna laborjában a kulcskísérleteket elvégző Martin Jínek mind kulcsszereplői ennek a történetnek, hogy csak néhány nevet említsünk. És persze nem hagyható ki Virginijus Šikšnys sem, aki Doudna és Charpentier cikkével szinte párhuzamosan publikálta saját csoportjának nagyban átfedő eredményeit.

Mostanra világossá vált, hogy a fágok és baktériumok közti évmilliárdos fegyverkezési verseny eredményének megértése évi milliárd dolláros biotech üzletág megjelenésének (és ezzel együtt vég nélküli szabadalmi vitáknak) ágyazott meg. Azonban az, ahogy eljutottunk ide egy szokatlan szekvenciaismétlődés tanulmányozásától, jól mutatja, nem jósolható meg, melyik alapkutatási kérdés lesz az, amelynek pontosabb megértése igazi alkalmazott áttörést is hozhat. 